\title{
ULTRASONIC-ASSISTED EXTRACTION OF ANTIOXIDANT PHENOLIC COUMPOUNDS FROM EUCHEUMA COTTONII
}

\author{
Dyah Hesti Wardhani $^{{ }^{*} \text { ) }}$, Denni Kartika Sari ${ }^{2)}$, and Aji Prasetyaningrum ${ }^{1)}$ \\ ${ }^{1)}$ Department of Chemical Engineering-Diponegoro University \\ Jl. Prof. Soedarto, Kampus UNDIP Tembalang, Semarang 50275, Indonesia \\ Telp.:+62 24746 0058, Fax.: +62 2476480675 \\ ${ }^{2)}$ Department of Chemical Engineering-Tirtayasa University \\ Jl. Jendral Sudirman KM 3, Cilegon, Banten, 42435, Indonesia \\ ${ }^{*}$ Corresponding author: dhwardhani@undip.ac.id
}

\begin{abstract}
The influences of ultrasonic-assisted extraction (UAE) conditions on phenolic compounds of Eucheuma cottonii seaweeed were investigated. The effects of temperature, time and liquid-solid ratio were evaluated based on the total phenolic content (TPC). The result showed a significant variability of effect of temperature, time, and liquid-solid ratio on TPC. Application of ultrasound reduced the optimum temperature, time and liquid-solid ratio of the extraction when compared to the conventional extraction. The highest phenolic content (4.44 mg gallic acid equivalent/g dry weight) was obtained at 3:1(v/w) of liquid-solid ratio, $55^{\circ} \mathrm{C}$ of temperature and $35 \mathrm{~min}$ of extraction time. At this condition, the extract showed ability to scavenging 91\% of 1,1-diphenyl 2 picrylhydrazyl (DPPH radical) and 10.9\% of $\mathrm{H}_{2} \mathrm{O}_{2}$. High ability of the extract to scavenge DPPH radical but low in scavenging $\mathrm{H}_{2} \mathrm{O}_{2}$ indicated that the extract dominated by primary antioxidant compounds which work by donating hydrogen atoms to bind free radical.
\end{abstract}

Keywords: antioxidant; DPPH radical; Eucheuma cottonii; $\mathrm{H}_{2} \mathrm{O}_{2}$; phenolic coumpounds; ultrasonic-assisted extraction

\begin{abstract}
Abstrak
EKSTRAKSI BERBANTU ULTRASONIK SENYAWA FENOLIK ANTIOKSIDAN DARI EUCHEUMA COTTONII. Penelitian ini mempelajari pengaruh kondisi operasi ekstraksi berbantu gelombang ultrasonik terhadap perolehan senyawa fenolik Eucheuma cottonii. Peubah-peubah yang dipelajari meliputi pengaruh suhu, waktu dan rasio cairan-padatan terhadap kadar fenol total (TPC) pada ekstraksi berbantu gelombang ultrasonik. Hasil penelitian menunjukkan bahwa pengaruh peubah-peubah operasi tersebut cukup beragam. Pemaparan gelombang ultrasonic pada proses ekstraksi tersebut terbukti menurunkan suhu, waktu dan rasio cairan-padatan yang optimum disbanding dengan metode ekstraksi konvensional. Kadar senyawa fenolic tertinggi (4,44 mg ekuivalen asam galat/g berat kering) dicapai pada ekstraksi menggunakan rasio cairan-padatan 3:1(v/w) pada suhu $55^{\circ} \mathrm{C}$ selama 35 menit. Ekstrak yang diperoleh pada kondisi ini menunjukkan kemampuan antioksidasi melawan 1,1-diphenyl 2 picrylhydrazyl (radikal DPPH) dan hidrogen peroksida, masing-masing sebesar 91\% dan 10,9\%. Perbedaan yang mencolok dalam aktivitas antioksidasi ini menunjukkan bahwa ekstrak E. cottonii didominasi oleh senyawa antioksidan primer yang bekerja dengan menyumbangkan atom hydrogen untuk mengikat radikal bebas.
\end{abstract}

Kata kunci: antioksidan; radikal DPPH; Eucheuma cottonii; $\mathrm{H}_{2} \mathrm{O}_{2}$; senyawa fenolik; ekstraksi berbantu gelombang ultrasonic

\section{INTRODUCTION}

Many synthetic antioxidants, such as butylated hydroxyl toluene (BHT) and tert-butyl hydroxyl quinone (TBHQ) have been reported to have potential health hazards. These antioxidants have been restricted for use in foods as they are suspected to be carcinogenic. Hence their use as food additives is under strict regulation in many countries. These conditions, together with recent consumers' interests in natural product, have driven the search of natural antioxidant sources as alternatives to replace synthetic 
antioxidants in preventing oxidation in complex food systems (Romero et al., 2004).

Owing to their high polyphenol content, macro algae are gaining interest as potential natural sources of antioxidant compounds from marine plant. Methanol extracts of red and brown algae had been identified to contain a series of polyphenolic compounds such as catechins (e.g. gallocatechin, epicatechin and catechingallate), flavonols and flavonol glycosides. These compounds demonstrated a great capacity in capturing free radicals which cause oxidative stress and helping in preventing some types of cancers (Wang et al., 2009). Kappaphycus alvarezii (Doty) Doty ex P.C. Silva also known as Eucheuma cottonii belongs to a red algae has been cultured and utilized for source of traditional remedies as well as food materials in Asian countries, such as carrageenan and antioxidant (Wang et al., 2009). The algae powder showed ability to decrease total cholesterol, low density lipoprotein (LDL), triglyceride, and increase the level of high density lipoprotein (HDL) and superoxide dismutase (SOD) status in the liver tissues of hypercholesterolemic rats (Wresdiyati et al., 2008). Kumar et al. (2008) reported that the total phenol content of various solvent extracts of $K$. alvarezii varied from 0.683 to $2.05 \%$. Among the extracts obtained, the methanol extract showed the highest chelating activity and reducing power. Moreover, their reducing power and hydroxyl radical scavenging activities of Kappaphycus were higher compared to atocopherol.

Previous researches applied maceration in extracting phenolic compounds of E. cottonii (Damongilala et al., 2013). Maceration is a simple extraction method which requires a long extraction time and more consumption of solvent. In addition, most active ingredients of plants are found in the $E$. cottonii cells, making it difficult for mechanical crushers to break cells for extraction, while chemical crushing methods may damage the active molecules and inactivate the extract (Lai et al., 2013). Developing a fast and efficient way for production a high quality of botanical products has become an issue of concern in pharmaceutical and food industries to outcome the problem of the existing methods.

Much attention has been given to apply ultrasound for the extraction of natural products. Compared to conventional extraction, ultrasoundassisted extraction (UAE) permits to achieve complete extraction in shorter time, reduce solvent consumption, increase yield of extracted components and increase rate of extraction. The enhancement of UAE efficiency is attributed to a phenomenon of cavitations bubbles produced in the solvent as a respond to an ultrasonic wave. During expose to the wave, the cavitation bubbles are able to grow and finally collapse when they reach a critical point. The implosion of cavitation bubbles generates macroturbulence, high-velocity inter-particle collisions and perturbation in micro-porous particles of solid material which accelerates internal diffusion. When these bubbles collapse onto the surface of a solid material, the bubbles release micro jets directed towards solid surface that result in surface peeling, erosion and particle breakdown which allowing higher penetration of the solvent into solid particles and the intracellular product compounds released by disrupting the cell walls. A great performance was reported in application of UAE to extract herbal, oil, protein and bioactive and functional compounds e.g. polyphenolics, anthocyanins, aromatic compounds, polysaccharides from variety of matrices such as plant and animal materials. Moreover, it was reported that applications of UAE improved the extraction yield of bioactive compounds by $6-35 \%$ compared to conventional process (Chemat et al., 2011; Vilkhu et al., 2008).

In general, solvent type, solid to solvent ratio, time, temperature and ultrasound power are influential parameters for extracting phenolic compound by using UAE. Unfortunately, study of UAE application for extracting phenolic compounds of E. cottonii has not been explored. Hence, this study was aimed to determine the effect of UAE parameters on antioxidant compounds of E. cottonii. The antioxidant extracts were determined as total phenolic content, ablity to scavenge free radicals of DPPH radical and activity to scavenging $\mathrm{H}_{2} \mathrm{O}_{2}$.

\section{MATERIALS AND METHODS Materials}

Fresh E. cottonii was obtained from Karimun Java (Central Java, Indonesia). The plant was dried at $55^{\circ} \mathrm{C}$ for 48 hour, and ground into powder. Folin Ciocalteu Reagent (FCR), $\mathrm{Na}_{2} \mathrm{CO}_{3}$ (99\%), gallic acid (99\%), and methanol (90\%) were purchased from Merck, while 1,1 Diphenyl 2-picrylhydrazyl (DPPH radical, 90\%) and $\mathrm{H}_{2} \mathrm{O}_{2}$ were obtained from Sigma Aldrich.

\section{Ultrasonic-Assisted Extraction}

One gram of E. cottonii powder was mixed with $10 \mathrm{~mL}$ of methanol in $100 \mathrm{~mL}$ of volumetric flask and covered with aluminum foil. The extraction flask was then placed in an ultrasonic bath (Krisbow DSA50-GL). The extractions were set for various temperatures $\left(35-60^{\circ} \mathrm{C}\right)$, times $(10-45 \mathrm{~min})$ and ratio of liquid-solid (3:1-10:1 v/w). After the extraction, the extract was filtered and analyzed for antioxidant activities.

\section{Total Phenolic Content (TPC)}

The total phenolic content of the extracts was determined using the method of Waterhouse (1999). Brieflyan aliquot of the sample $(0.2 \mathrm{~mL})$,distilled water $(15.8 \mathrm{~mL})$ and FCR $(1 \mathrm{~mL})$ was placed in capped test tubes. After addition of $10 \mathrm{~mL}$ of sodium carbonate ( $20 \% \mathrm{w} / \mathrm{w})$, the tubes were vortexed for 10 min then allowed the mixture to react at room temperature for 2 hours. The absorbance of the 
mixture was measured at $765 \mathrm{~nm}$ using spectrophotometer (Optima SP 300, Japan) compared to the blank. The amount of total phenolic content was expressed as gallic acid equivalents (mg GAE/g dry weight).

\section{1,1 Diphenyl 2-picrylhydrazyl Scavenging Sctivity (DPPH-SA)}

The DPPH-SA assay was carried out following the procedure of Banerjee et al. (2005). An aliquot of extract $(1.0 \mathrm{~mL})$ was added to solution of DPPH radical (3 $\mathrm{mL}, 0.1 \mathrm{mM}$ ) freshly prepared, and then kept the mixtures in the dark for $30 \mathrm{~min}$.The absorbance of the mixture was read using a spectrophotometer at $517 \mathrm{~nm}$ (Optima SP 3000, Japan). Activity of the extract to DPPH-SA was expressed as:

DPPH radical scavenging activity $(\%)=\frac{\left(A_{\text {blank }}-A_{\text {sample }}\right)}{A_{\text {blank }}} \times 100 \%(1)$

\section{Hydrogen Peroxide Scavenging Activity (HP-SA)}

The HP-SA assay was carried out base on the procedure of Ruch et al., (1989). A solution of $\mathrm{H}_{2} \mathrm{O}_{2}$ (43 mM) was mixed with phosphate buffer $(0.1 \mathrm{M}$, pH $7.4)$ in ratio $1: 4(\mathrm{v} / \mathrm{v})$. An aliquot of extract $(1.0 \mathrm{~mL})$, a solution of phosphate buffer (2.4 mL, pH 7.4, $0.1 \mathrm{M})$ and a solution of $\mathrm{H}_{2} \mathrm{O}_{2}$-phosphate buffer $(0.6 \mathrm{~mL})$ were placed in test tube. The absorbance of the mixture was read at $230 \mathrm{~nm}$ using spectrophotometer (Optima SP 300, Japan) after 40 min incubation at dark room. The $\mathrm{H}_{2} \mathrm{O}_{2}$-phosphate solution was used as the blank. The HP-SA was determined as:

$$
\mathrm{H}_{2} \mathrm{O}_{2} \text { scavenging effect }(\%)=\frac{\left(A_{\text {blank }}-A_{\text {sample }}\right)}{A_{\text {blank }}} \times 100 \%
$$

\section{RESULTS AND DISCUSSION}

In this study, effects of temperature, time and solvent-solid ratio of UAE on antioxidant activity of E. cottonii were studied. All the obtained extracts were measured for TPC. The extracts of solvent-solid ratio were subsequently determined for DPPH-SA and HP-SA.

\section{Effect of UAS Temperature on TPC}

Figure 1 shows the gradual increase of TPC in line with the increase of temperature from 35 to $55^{\circ} \mathrm{C}$. The results showed that the solubility and diffusion of phenolic compounds from E. cottonii matrix particles into the extraction medium increased with temperature.The increase of extraction temperature allowed permeability of cell wall to increase while viscosity of solvent decrease. This increased diffusivity of the solvent in the solid matrix and the solubility of the phenolic compounds in the solvent, which lead to more compounds extracted. Moreover, the decrease of the solvent viscosity permitted to reduce tensile surface and encouraged more cavitations intensity which in turn extracted higher phenolic compounds and accelerated UAE. Similar trends in the relationship of TPC and extraction temperature have been reported by Liu et al. (2010) who studied the chlorogenic acid of Folium eucommiae.

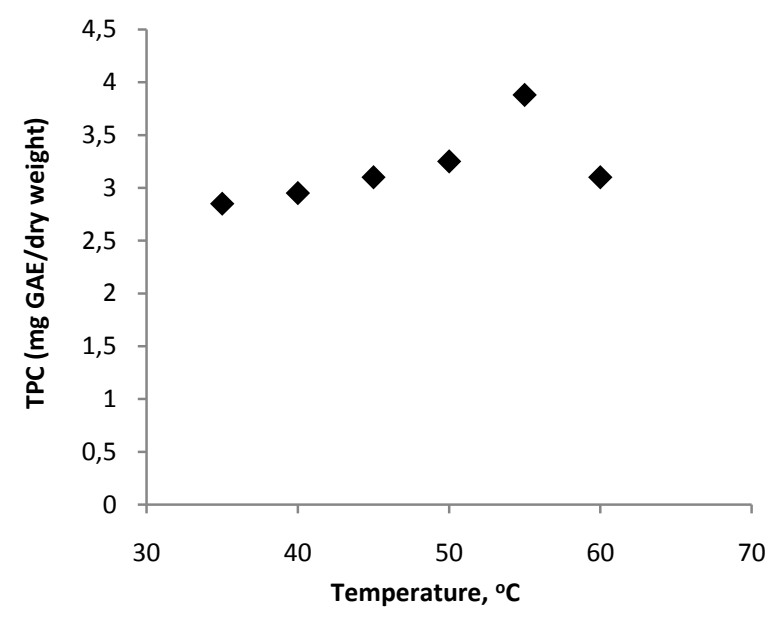

Figure 1. Effect of UAE temperature on the total phenolic content (TPC) of red algae E. cottonii

This study showed the TPC of red seaweed reached the maximum value (3.88 $\mathrm{mg}$ GAE/g dry weight) at $55^{\circ} \mathrm{C}$ of UAE. Heo et al. (2005) found $70^{\circ} \mathrm{C}$ as the best extraction temperature of the antioxidant compound of various seaweeds. At this temperature they obtained 1.04-109.36 mg/g dry weight sample of the phenolic concentration after extraction for $24 \mathrm{~h}$, depend on the seaweed species. The different in the best extraction temperature indicated that application of ultrasound reduced the optimum extraction temperature of the phenolic compared to the conventional extraction. Indirect heat transfer process was observed in the conventional method where temperature gradient was the driving force. In this process, the heat gradually propagates from solvent to the solid. Meanwhile, direct contact between solid and ultrasonic wave in UAE allow achieving lower optimum temperature compared to the conventional extraction. Ultrasound aids a mechanical effect by continuous compression and evacuation cycle allowing greater penetration of solvent into the sample matrix, increasing the contact surface area between the solid and liquid phase, as a result the solute quickly diffuses from the solid phase to the solvent (Rostagno et al., 2007). Phenolic compounds were unstable in higher temperature. Therefore, high extraction temperature might enhance extract impurities due to co-extraction of other undesirable compounds (Liu et al., 2010).

It should also be noted that although increasing temperature could improve the TPC, improvement of temperature beyond a certain value can lead to decomposition of some phenolic compounds. In this study, exposure the seaweed at higher extraction temperature than $55^{\circ} \mathrm{C}$ allowed the phenolic compounds to be decomposed during UAE thus reduced TPC. Therefore, it is important to select the correct range of extraction temperature to be studied in order to obtain the best antioxidant performance. 


\section{Effect of UAS Time on TPC}

TPC increased along with the extension of the extraction time (Figure 2). The results showed $35 \mathrm{~min}$ as the optimum extraction time of TPC of E. cottonii, which obtained $4.2 \mathrm{mg}$ GAE/g dry weight. Solidliquid extraction is a mass transport phenomenon in which compounds in solid matrix migrate into solvent by diffusion and osmotic mechanism which induced by ultrasounds. Application of ultrasound in solidliquid extraction forms cavitations bubbles which break the plant cells to facilitate penetration of solvent into the cells. The penetration facilitates swelling and hydration, causing an enlargement in the pores of the cell wall, which improves the diffusion process and leading to enhance mass transfer (Bilgin and Shahin, 2013). This result agreed that extraction time is an important variable in UAE of phenolic compounds from plant materials. A longer extraction time permits more contact time for the cavitation bubbles to rupture more plant cells, result in an increase of the TPC extracted (Wang et al., 2012). The result was in accordance with Han et al. (2012) who reported the improvement of phenolic of Betel nut seed with time by using UAE method, respectively.

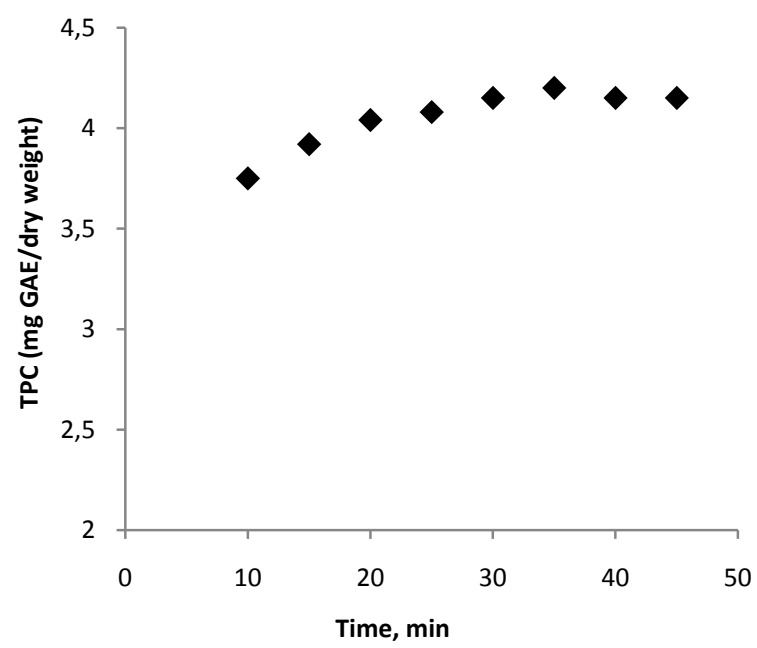

Figure 2. Effect of UAE time on the total phenolic content (TPC) of red algae E. cottonii

However, Chew et al. (2011) found that prolonging extraction time no longer affect the phenolic level of Orthosiphon stamineus significantly when the diffusion process had reached equilibrium. Figure 2 shows TPC no longer significantly improved when extraction time was longer than $35 \mathrm{~min}$. Extension of extraction time over the equilibrium time leads the phenolics to be exposed to light and oxygen in longer period. This exposure allowed the phenolic compounds to be oxidized which in turned decrease the obtained TPC. Moreover, prolonging the extraction time may cause accumulation of compounds that could promote oxidation (Bazykina et al., 2002). This research showed that UAE for over 35 minutes could lead the phenolics of $E$. cottonii to be oxidized.

The mechanism of UAS kinetic, as showed by Figure 2 is in agreement with the result of Bilgin and Shahin (2013). They proposed that UAS mechanism has 2 stages of extraction. At the beginning of the extraction, dissolution of soluble components on surfaces of the plant matrix occurs. This first stage results in a rapid increase of TPC. The next stage is mass transfer of the solute from the plant matrix into the solvent by diffusion and osmotic processes, which is slower process. In this study, slightly raise of TPC was observed over $35 \mathrm{~min}$. Therefore, $35 \mathrm{~min}$ was accepted as the optimum time in this process.

The maximum TPC obtained in this research (4.40 mg GAE/g dry weight) was lower than TPC of Damongilala et al. (2013) who obtained $5.87 \mathrm{mg}$ GAE/g dry weight for extracting phenolic of $E$. cottonii. However, Damongilala et al. (2013) conducted the study by maceration for $3 \times 24$ hour compared to this study by using UAS for 35 min only. Hence, this study confirmed that UAS reduce the extraction time. This study showed higher result of TPC than report of Chew et al. (2008) who found TPC of $E$. cottonii was $115 \pm 35 \mathrm{mg} \mathrm{GAE} / 100 \mathrm{~g}$ dry weight after 1 hour maceration.

\section{Effect of Liquid-Solid Ratio on TPC}

Effect of solvent-solid ratio of UAE on TPC is presented in Figure 3. The highest TPC $(4.440 \mathrm{mg}$ GAE/g dry weight) was obtained at 3:1 of the liquidsolid ratio. However, there was insignificant change of TPC obtained at solvent-solid ratio studied (3:1-10:1, $\mathrm{v} / \mathrm{w})$. Result of this study was in line with other UAE reports. Oancea et al. (2013) also reported insignificant different of antocyanin of black gold sweet cherry at 10:1-20:1 (v/w) for 20 min by using UAE. Petigny et al. (2013) reported insignificant effect of solid-solvent ratio at $4-10 \%$ on yield of UAE Boldo leaf.

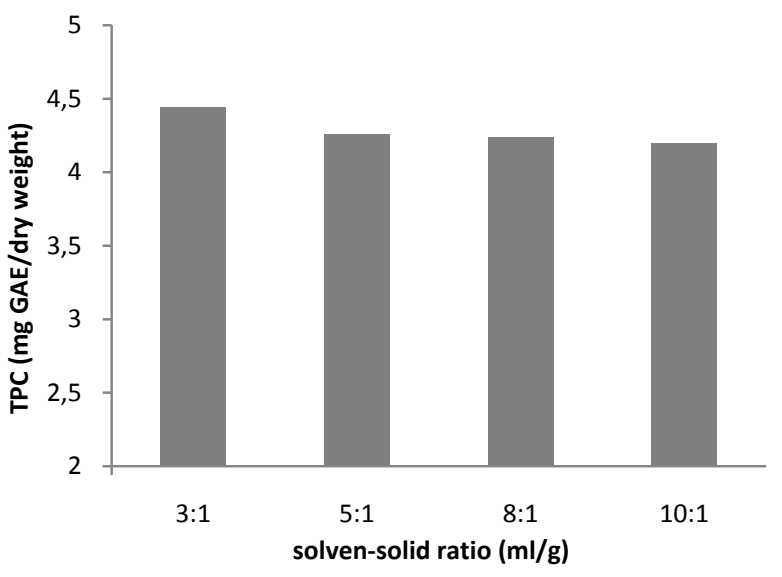

Figure 3. Effect of UAE solvent-solid ratio (v/w) on the total phenolic content (TPC) of red algae $E$. cottonii 
In coventional extraction techniques such as maceration, higher volume of solvent will increase the extract yield but too much solvent is inefficient. In UAE, the ultrasound wave creates frictions between solid samples. The frictions produce heat and allow cavitation bubbles to damage the cell wall and accelerate the extraction of the phenolic compounds. Addition of solvent volume cause more distance between the solid particles thus reduce the frictions (Tcholakova et al., 2008). This result showed application of UAE allowed to apply less solvent, which in turn reduced cost in extraction process.

\section{Effect of Liquid-solid Ratio on DPPH Radical Scavenging Activity (DPPH-SA)}

A 1,1-diphenyl-2-picryhydrazyl (DPPH) compound is a stable free radical that possesses a nitrogen free radical that is commonly used to measure the antioxidant activity of tissue extracts. The free radical is unpaired electron which unstable and highly reactive molecule. Scavenging activity of DPPH radicals by the antioxidant occurs through proton donation to the radical. Compound that is able to donate its proton shows strong radical scavenging activity. The phenolic compounds release their hydrogen atoms to bind to the 1,1-diphenyl-2picrylhydrazyland subsequently change into 1,1diphenyl-2-picryl hydrazine non radical. The latest formed is stable and do not attack other molecules to form a new radical. An increasing number of 1,1diphenyl-2-picryl hydrazine non radicals will be marked with changing color from purple to yellow.

The DPPH-SA of the extracts in various solvent-solid ratios are presented in Figure 4. This figure shows increasing solvent volume reduced the ability of extract to scavenge radical DPPH. The highest DPPH-SA was obtained at 3:1 solvent-solid ratio which was around 91\%. This trend was in line with the result of TPC (Figure 3). The higher content of TPC implied the extract contained more hydrogen atoms to bind more DPPH radicals due to increasing number of DPPH radicals stabilized by hydrogen atom donors derived from the phenolic compounds and turn them into non-radical compounds. Previous studies have shown that phenolic compounds are the main contributors on the antioxidant activity of various seaweeds. A positive correlation has been documented between TPC and antioxidant activities of different seaweed extracts by many researchers (Wang et al., 2009). However, these antioxidant assays were not specific to any particular antioxidants. This result showed although the TPC content slightly improved, however, the DPPH-SA significantly rose. The result suggested that the extract could also contain other compounds than phenolics which also have strong radical scavengers. Souza et al. (2012)reported red seaweed contains galactose, 3,6-anhydrogalactose and 6-O-methylgalactose which are sulfate polysaccharides and showed ability to inhibit DPPH radical. Chew et al. (2008) who studied antioxidant activity of three seaweeds found $K$. alvarezzi showed higher activity in scavenging DPPH radical than $C$. racemosa, although TPC of the later seaweed was higher that of $K$. alvarezzi.

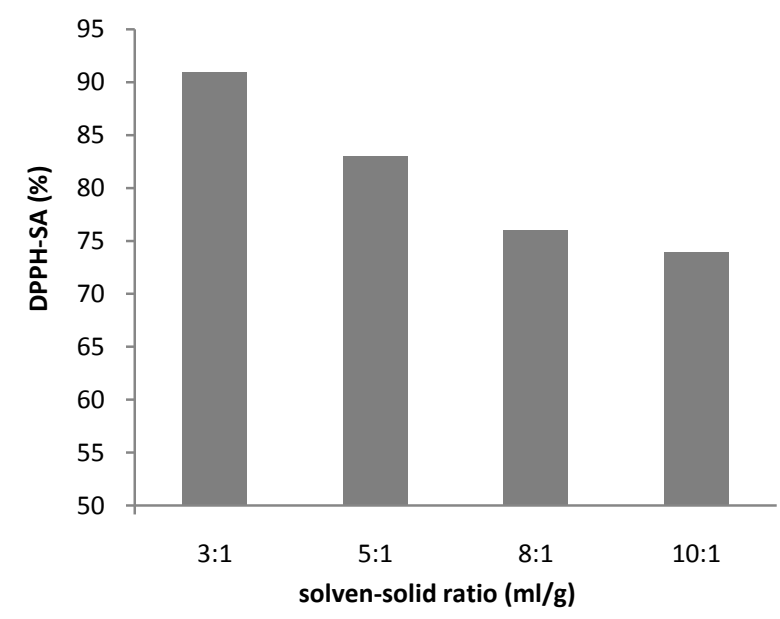

Figure 4. Effect of UAE solvent-solid ratio (v/w) on $\mathrm{DPPH}$ radical scavenging activity (DPPH-SA) of red algae E. cottonii

Although lower in TPC, the DPPH-SA result of this study was higher than the result of Damongilala et al. (2013) who showed only $69 \%$ as the best DPPHSA. This higher of DPPH-SA value indicated that shorter extraction time allowed protecting the antioxidant compounds of the extract from exposed to environments including oxygen and light which was trigger to oxidation during the extraction process, as discussed at Effect of UAS Time on TPC

\section{Effect of Liquid-Solid Ratio on $\mathrm{H}_{2} \mathrm{O}_{2}$ Scavenging Activity (HP-SA)}

This analysis of antioxidant performance is base on the phenomenon of transition metals such as $\mathrm{Fe}^{2+}$ or $\mathrm{Cu}^{-}$which catalyze formation of the hydroxyl radical from $\mathrm{H}_{2} \mathrm{O}_{2}$ in the body through non enzymatic Fenton reaction. $\mathrm{H}_{2} \mathrm{O}_{2}$ is a weak oxidizing agent, not a free radical. Moreover, $\mathrm{H}_{2} \mathrm{O}_{2}$ is also the precursor of hypochlorous acid ( $\mathrm{HOCl})$, a powerful oxidizing agent. Scavenging of $\mathrm{H}_{2} \mathrm{O}_{2}$ by antioxidants is essential for the body's defense mechanisms to inhibit free radical formation caused by Fenton reaction (Smith et al., 2004). The antioxidant that scavenging non radical such as $\mathrm{H}_{2} \mathrm{O}_{2}$ known as secondary antioxidant which offers their antioxidant activity by deactivating the active species and possible precursors of free radicals (Yanishlieva, 2001).

The scavenging ability of phenolic compounds of E. cottonii on $\mathrm{H}_{2} \mathrm{O}_{2}$ is presented in Figure 5. This figure shows the more solvent applied, the less HP-SA of the extract observed. Figure 5 shows a similar trend of liquid-solid ratio on HP-SA with that on DPPH-SA. Although the extract demonstrated high ability to bind DPPH radicals (91\%), the maximum HP-SA of the extract was only $10.95 \%$ which obtained at $3: 1$ of liquid-solid ratio. Similar result was reported by Pise 
et al. (2010) who found HP-SA of the phenolics from Porphyraindica seaweed was only $10 \%$ after $24 \mathrm{~h}$ maceration. This result was lower than HP-SA of BHA which was $44.58 \%$.

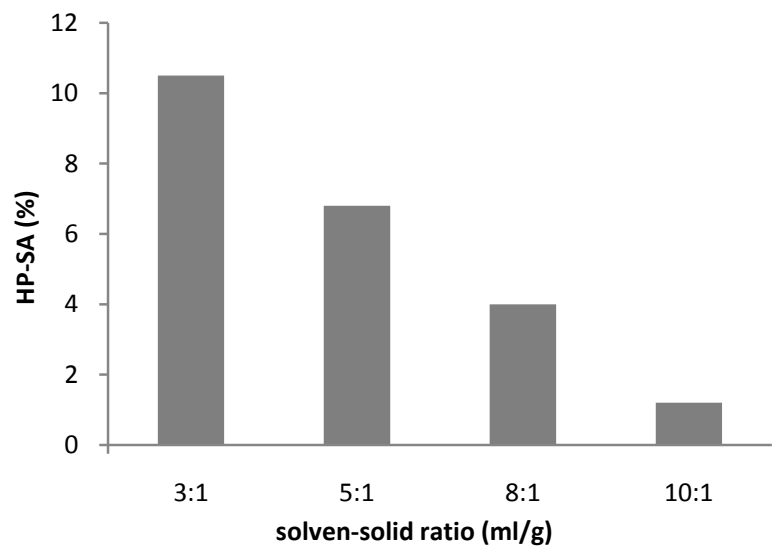

Figure 5. Effect of UAE solvent-solid ratio (v/w) on $\mathrm{H}_{2} \mathrm{O}_{2}$ scavenging activity (HP-SA) of red algae $E$. cottonii

A significant different ability of the extract toward DPPH-SA and HP-SA suggested that the extract contained mostly primary antioxidant compounds rather than secondary ones. Primary antioxidant works as radical chain breaker by donating hydrogen atoms to bind radical and convert it into stable molecule (Frankel, 2005). High value of DPPHSA indicated that the extract comprised of hydrogen atoms which are able to scavenging up to $91 \%$ of radical DPPH. This result was in line with Wang et al. (2009) who postulated that the major role of algal antioxidants is a radical scavengers and primary chainbreaking antioxidants. Hence, it was suggested that the extract contained minor amount of secondary antioxidant compounds that work as non radical inhibitor which will react with $\mathrm{H}_{2} \mathrm{O}_{2}$. This low in secondary antioxidant content resulted in low ability to scavenging $\mathrm{H}_{2} \mathrm{O}_{2}$.

\section{CONCLUSION}

This study showed that the maximum TPC of seaweed E. cottonii obtained by UAE at $55^{\circ} \mathrm{C}, 35 \mathrm{~min}$ and 3:1 (v/w) solvent-solid ratio was $4.44 \mathrm{mg} \mathrm{GAE} / \mathrm{g}$ dry weight. The TPC of the extract had a positive correlation with scavenging DPPH radical, which maximum was 91\%. Regardless, positive correlation between TPC and HP-SA, the extract only showed just above $10 \%$ on scavenging $\mathrm{H}_{2} \mathrm{O}_{2}$. Hence, it was suggested that the extract comprised of primary antioxidant as a major antioxidant compounds which work by binding free radical. This study confirmed that the antioxidant assay could have a great effect on determining antioxidant effectiveness. It requires further studies to understand the detail antioxidant compounds of E. cottonii and their action in performing antioxidant on different antioxidant assays.

\section{REFERENCES}

Banerjee, A, Dasgupta, N, and Dee, B., (2005), In vitro study of antioxidant activity of Syzygium cumini fruit, Food Chemistry, 90(4), pp. 727-733.

Bazykina, N.I, Nikolaevskii, A.N., and Fillipenko, T.A., (2002), Optimization of conditions for the extraction of natural antioxidants from raw plant materials, Pharmaceutical Chemistry Journal, 36(2), pp. 46-49.

Bilgin, M. and Ahin, S., (2013), Effects of geographical origin and extraction methods on total phenolic yield of olive tree (Olea europaea) leaves, Journal of the Taiwan Institute of Chemical Engineers, 44(1), pp. 8-12.

Chemat, F., Zill-e-Huma, and Khan, M.K., (2011), Applications of ultrasound in food technology: Processing, preservation and extraction, Ultrasonics Sonochemistry, 18(4), pp. 813-835.

Chew, Y., Lim, Y., Omar, M., and Khoo, K., (2008), Antioxidant activity of three edible seaweeds from two areas in South East Asia, LWT Food Science and Technology, 41(6), pp. 1067-1072.

Chew, K.K., Khoo, M.Z., Ng, S.Y., Thoo, Y.Y, and Aida, W.H.C., (2011), Effect of ethanol concentration, extraction time and extraction temperature on the recovery of phenolic compounds and antioxidant capacity of Orthosiphon stamineus extracts, International Food Research Journal, 18(4), pp. 14271435.

Damongilala, L.J., Widjanarko, S.B., Zubaidah, E., and Runtuwene, M.R.J., (2013), Antioxidant Activity Against Methanol Extraction of Eucheuma cottonii and E. spinosum Collected From North Sulawesi Waters, Indonesia, Food Science and Quality Management, 17, pp. 7-14.

Frankel, E.N., (2005), Lipid Oxidation (2nd ed.), Cambridge: Wooodhead Publishing.

Han, L, Hai, D.Z, Shi, S.L, and Kai, L., (2012), Optimization of ultrasound-assisted extraction of nut seed and evaluation of antioxidant activity in vitro, African Journal of Biotechnology, 10, pp. 9289-9296.

Heo, S.J., Park, E.J., Lee, K.W., and Jeon, Y.J., (2005), Antioxidant activities of enzymatic extracts from brown seaweeds, Bioresource Technology, 96(14), pp. 1613-1623.

Kumar, K.S., Ganesan, K., and Rao, P.V.S., (2008), Antioxidant potential of solvent extracts of Kappaphycus alvarezii (Doty) Doty - An edible seaweed, Food Chemistry, 107(1), pp. 289-295.

Lai, J., Xin, C., Zhao, Y., Feng, B., He, C., Dong, Y., and Wei, S., (2013), Optimization of ultrasonic assisted extraction of antioxidants from black soybean 
(Glycine max var) sprouts using response surface methodology, Molecules, 18(1), pp. 1101-1110.

Liu, Q.M., Yang, X.M., Zhang, L., and Majetich, G., (2010), Optimization of ultrasonic-assisted extraction of chlorogenic acid from Folium eucommiae and evaluation of its antioxidant activity, Journal of Medicinal Plants Research, 4(23), pp. 2503-2511.

Oancea, S., Grosu, C., Ketney, O., and Stoia, M., (2013), Conventional and Ultrasound-Assisted Extraction of Anthocyanins from Blackberry and Sweet Cherry Cultivars, Acta Chim. Slov., 60(2), pp. 383-389.

Petigny, L., Périno-Issartier, S., Wajsman, J., and Chemat, F., (2013), Batch and Continuous Ultrasound Assisted Extraction of Boldo Leaves (Peumus boldus Mol.), International Journal of Molecular Sciences, 14(3), pp. 5750-5764.

Pise, N., Jena, K., Maharana, D., Gaikwad, D., Jagtap, T., and Paula, D., (2010), Free radical scavenging potential, reducing power, phenolic and biochemical constituents of Porphyra species from India, J. Algal Biomass Utln., 1(3), pp. 29-42.

Romero, A.M, Doval, M.M, Sturla, M.A, and Judis, M.A., (2004), Antioxidant properties of polyphenolcontaining extract from soybean fermented with Saccharomyces cereviceae, Eur. J. Lipid Sci. Technol., 106, pp. 424-431.

Rostagno, M., Palma, M., and Barroso, C.G., (2007), Ultrasound-assisted extraction of isoflavones from soy beverages blended with fruit juices, Analytica Chimica Acta, 597(2), pp. 265-272.

Ruch, R.J., Cheng, S.J., and Klaunig, J.E., (1989), Prevention of cytotoxicity and inhibition of intercellular communication by antioxidant catechins isolated from Chinese green tea, Carcinogenesis, 10(6), pp. 1003-1008.

Smith, C.M, Marks, A.D, and Lieberman, M.A., (2004), Marks' basic medical biochemistry: a clinical approach (2nd ed.), Baltimore, MD: Lippincot Williams and Wilkins.
Souza, B.W.S., Cerqueira, M., Bourbon, A.I., Pinheiro, A.C., Martins, J.T., Teixeira, J., and Vicente, A., (2012), Chemical characterization and antioxidant activity of sulfated polysaccharide from the red seaweed Gracilaria birdiae, Food Hydrocolloids, 27(2), pp. 287-292.

Tcholakova, S, Denkov, N.D, and Lips, A., (2008), Comparison of solid particles globular proteins and surfactans as emulsifiers, Physical Chemistry Chemical Physics, 10(12), pp. 1608-1627.

Vilkhu, K., Mawson, R., Simons, L., and Bates, D., (2008), Applications and opportunities for ultrasound assisted extraction in the food industry - A review. Innovative Food Science and Emerging Technologies, 9(2), pp. 161-169.

Wang, T., Jonsdottir, R., and Olafsdottir, G., (2009)., Total phenolic compounds, radical scavenging and metal chelation of extracts from Icelandic seaweeds. Food Chemistry, 116(1), pp. 240-248.

Wang, X., Wu, Q., Wu, Y., Chen, G., Yue, W., and Liang, Q., (2012), Response Surface Optimized Ultrasonic-Assisted Extraction of Flavonoids from Sparganii Rhizoma and Evaluation of Their in Vitro Antioxidant Activities. Molecules, 17(6), pp. 67696783.

Waterhouse, A., (1999), Folin-Ciocalteau Micro Method for Total Phenol in Wine. Retrieved December 17, 2013, from http://waterhouse.ucdavis.edu/faqs/folin-ciocalteaumicro-method-for-total-phenol-in-wine

Wresdiyati, T., Hartanta, A.B., and Astawan, M., (2008), The Effect of Seaweed Eucheuma cottonii on Superoxide Dismutase (SOD) Liver of Hypercholesterolemic Rats, Hayati Journal of Biosciences, 15(3), pp. 105-110.

Yanishlieva, N.V., (2001), Inhibiting oxidation. In Y. Pokorny, J and M.H.N.V, and Gordon (Eds.), Antioxidants in food: practical applications. Boca Raton: Woodland Publishing Ltd. 